\title{
An Empirical Study on Questioning Style in Higher Vocational College English Classroom in China
}

\author{
Li-Zhi Shu ${ }^{1}$ \\ ${ }^{1}$ Department of Applied Foreign Languages, Guangdong Polytechnic College, Guangzhou, China \\ Correspondence: Li-Zhi Shu, Department of Applied Foreign Languages, Guangdong Polytechnic College, \\ NO.18 Yuxing Road, Tianhe District, Guangzhou 510520, China. Tel: 86-189-2875-4075. E-mail: \\ soapyshu@163.com
}

Received: January 18, 2014 Accepted: March 8, 2014 Online Published: May 27, 2014

doi:10.5539/ells.v4n2p6 URL: http://dx.doi.org/10.5539/ells.v4n2p6

\begin{abstract}
This study investigates the effects of task-based language teaching (TBLT) reform in Higher Vocational College from the perspective of questioning style. It employs three methods to collect data: classroom observation, semi-structured interview and focus group discussion with 8 English teachers and their 545 non-English major students from 3 Higher Vocational Colleges in Guangdong. The results indicate that the teachers did assign students different tasks to perform in class and seemed to be adopting the TBLT approach, but their English classrooms have not totally changed from the teacher-centered grammar-focused ones to student-centered and communicative ones.
\end{abstract}

Keywords: higher vocational education, TBLT, referential question, high cognitive level question, question distribution

\section{Introduction}

Higher vocational education has been developing rapidly in China these years and higher vocational English teaching, as a significant part of Vocational Education in China, aims at developing the overall proficiency and emphasizes the importance of communicative competence in English. However, there has been contradiction between the objective and the traditional teacher-centered, examination-oriented approaches applied in English classes. In 2001 the Ministry of Education of China introduced the New English Language Curriculum Standard and recommended task-based language teaching (TBLT) which emphasizes on developing the students' integrative competence by means of experiencing, practicing, participating, communicating, cooperating and so on. From then on, more and more English teachers of vocational colleges have been trying this approach and they have spared no effort to promote reform of the English classroom from the teacher-centered grammar-focused one to a student- centered and communicative one. After ten years, how is this reform going? To investigate the effects of this reform, we want to find out whether the proposed reform has really changed the English classroom in China from the perspective of questioning style.

That we want to choose the questioning style for our study is due to the following reasons: questions are supposed to guide the learning and thinking of the students, reflect teacher's belief of what counts as effective teaching and learning, and demonstrate the role of both teacher and students (Tan, 2007). Therefore, the questions put forward in the classroom and the way the questions are posed can truly reflect the learning mode of the students and the teacher's focus in teaching. It can also show whether the English classroom is teacher-centered or student-centered.

\section{Question Types and Questioning Behavior}

Questions can and have been used for a wide variety of educational purposes: reviewing previously read or studied material; diagnosing students' abilities, preferences and attitudes; stimulating critical thinking; managing student behavior; probing students' thought process; stirring creative thinking; motivating students; and assessing student knowledge (Sari \& Litcher, 1998; Shen, 2012). In addition to the functions mentioned above, questions provide the most important opportunities for both students and the teacher to use the target language to negotiate meaning, gain comprehensible input, and test their hypothesis about language usage, all of which are considered crucial in language acquisition (Krashen, 1994; Long, 1996; Swain, 1995). 
There are different ways of classifying questions. This study will adopt the classification of questions as high cognitive level and low cognitive level questions (Bloom, 1956; McNeil, 2010), and referential and display questions (Long \& Sato, 1983).

Bloom (1956) divided questions into two levels: low cognitive level, which includes questions on knowledge, comprehension, and application; and high cognitive level, which include questions on analysis, synthesis and evaluation. The former types of questions mostly check students' simple recall of the information learned, while the latter demands more elaborative thinking.

Long and Sato (1983) divided questions into two types, display and referential questions. Display questions are those to which the answers are known and which are designed to elicit or display particular structures and knowledge, while referential questions are those to which teachers do not know the answers and often provide unique student insights, encourage exploration of many possibilities.

In TBLT classroom, high cognitive level questions play a much more important role than in the traditional classroom, and the reasons are closely related to the characteristics of TBLT and the nature of high cognitive level questions. Borich (1988) claimed that in an effective teaching class the most appropriate ratio of low cognitive level questions and high cognitive level questions should be about 70:30. But for a language class, the demand for high cognitive level behaviors is lower than other classes such as the general science classes, so the percentage of high cognitive level questions should be lower than $30 \%$. Based on the previous studies of question types in China's English classrooms (Wang, 2003; Tan, 2007; Han, 2007; Shen, 2012), which all found that high cognitive level questions were lower than $16 \%$, we think $20 \%$ would be an appropriate index of the TBLT nature of the English classroom in China.

As for referential questions, they should constitute the majority of the questions posed by the teacher which is the most outstanding and defining characteristic of questioning style in TBLT classroom. Compared with display questions, referential questions can generate more opportunities for authentic interactions and negotiation of meaning, elicit students' personal experience, their own opinions or personal response, and provide the context for authentic communication, which is essential in TBLT.

Apart from question types, the questioning behavior is also an important indication of language learning mode. We can study question distribution and initiator of questions to study the questioning behavior in an English classroom.

Question distribution refers to how the teacher assigns answering opportunities to students. Questions can be addressed to the whole class for an answer in chorus or to an individual. The former is known as "general solicit" while the latter "personal solicit" (Allwright \& Bailey, 1991, p. 124). It is considered desirable to use personal solicit and distribute questions to all students rather than restricting them to a few, for it can keep the learners alert and get them involved in the learning process. Besides, it also allows the learners equal opportunity to communicate with the teacher.

Questions can be initiated both by the teacher and the students. In a teacher- centered classroom, questions are predominantly put forward by the teacher. However, in a student-centered classroom, students will have more opportunities to ask questions. Since the students are responsible for their own learning, they are more likely to be initiative and active in asking questions about things they don't really understand.

Based on our research of the previous studies on question types and questioning behavior, we put forward four research questions for our study:

1) What is the frequency of display questions and referential questions raised by the teacher?

2) What is the frequency of low cognitive level questions and high cognitive level questions raised by the teacher?

3) What is the distribution of the questions raised by the teacher?

4) Do students initiate questions in the classroom with their teacher?

\section{Research design}

Three methods were used in our study to collect data: classroom observation, semi-structured interview with teachers and focus group discussion with students.

The participants of this study were 8 English teachers and their 545 non-English major students. They were from 3 Higher Vocational Colleges: a national model college (3 teachers), a provincial model college of Guangdong (3 teachers), and a common college of Guangdong ( 2 teachers). The 8 teachers teaching experience ranges from 
two to thirteen years. In addition, six of them had master degree, one got doctor degree and one bachelor degree.

The textbooks used advocates TBLT as its pedagogy. The lessons observed included reading, writing, listening and speaking. The 545 students were from 8 non-English major classes, from which three groups each containing 12 randomly sampled students took part in the focus group discussion.

A checklist was used during the classroom observation (see Appendix), and the 8 classes observed were recorded with MP3 to check against the content of the checklist.

In the semi-structured interview, the teachers were asked what the purpose of asking questions in class was, whether they knew referential and display questions, and high cognitive level and lower cognitive level questions, which type of questions they asked more, how they distributed questions in class, and whether they encouraged students to initiate questions in class.

In the focus group discussion, the students were asked what types of questions their teacher asked more, whether they had opportunities to answer the questions individually, whether they initiated questions in class and how they liked the questioning style in class.

The interviews and the focus group discussions were also recorded with MP3 and were later transcribed.

The classroom observation data were analyzed and categorized by two co-raters to ensure reliability. All the questions raised in the class were categorized into four types and entered into computer. A correlation analysis was conducted on the co-rating data, and the coefficient was 96.3 , which indicated that the two ratings were highly correlated $(\mathrm{p}=.000)$.

\section{Results and Discussion}

We first study the types of questions raised by the teachers in class. Table 1 presents the frequency of display and referential questions in the 8 classes:

Table 1. The frequency of display questions and referential questions

\begin{tabular}{c|ccccc}
\hline Teacher & $\begin{array}{c}\text { Total amount of } \\
\text { teachers' } \\
\text { questions }\end{array}$ & $\begin{array}{c}\text { Display } \\
\text { questions }\end{array}$ & Percent & $\begin{array}{c}\text { Referential } \\
\text { questions }\end{array}$ & Percent \\
\hline T1 & 62 & 54 & $87.1 \%$ & 8 & $12.9 \%$ \\
T2 & 111 & 92 & $82.9 \%$ & 19 & $17.1 \%$ \\
Level A & $\mathbf{1 7 3}$ & $\mathbf{1 4 6}$ & $\mathbf{8 4 . 4 \%}$ & $\mathbf{2 7}$ & $\mathbf{1 5 . 6 \%}$ \\
T3 & 76 & 57 & $75.0 \%$ & 19 & $25.0 \%$ \\
T4 & 80 & 56 & $70.0 \%$ & 24 & $30.0 \%$ \\
T5 & 92 & 64 & $69.6 \%$ & 28 & $30.4 \%$ \\
Level B & $\mathbf{2 4 8}$ & $\mathbf{1 7 7}$ & $\mathbf{7 1 . 4 \%}$ & $\mathbf{7 1}$ & $\mathbf{2 8 . 6 \%}$ \\
T6 & 83 & 41 & $49.4 \%$ & 42 & $50.6 \%$ \\
T7 & 100 & 30 & $30.0 \%$ & 70 & $70.0 \%$ \\
T8 & 78 & 31 & $39.7 \%$ & 47 & $60.3 \%$ \\
Level C & $\mathbf{2 6 1}$ & $\mathbf{1 0 2}$ & $\mathbf{3 9 . 1 \%}$ & $\mathbf{1 5 9}$ & $\mathbf{6 0 . 9 \%}$ \\
Total & $\mathbf{6 8 2}$ & $\mathbf{4 2 5}$ & $\mathbf{6 2 . 3 \%}$ & $\mathbf{2 5 7}$ & $\mathbf{3 7 . 7 \%}$ \\
\hline
\end{tabular}

Note. Level A=common level; Level $\mathrm{B}=$ provincial level; Level $\mathrm{C}=$ national level.

From the table we can see that the total amount of questions raised by the 8 teachers were 682 , among which 425 were display questions, accounting for $62.3 \%$, and 257 were referential questions, accounting for $37.7 \%$. The results show that in general, the questioning style was not desirable as the teachers asked more display questions than referential questions, which was inconsistent to the TBLT classroom.

A detailed analysis of the data revealed the differences among the teachers in colleges at different levels. In the Level A college, the two teachers asked 173 questions in total, among which 146 were displayed questions, and only 27 were referential questions, the ratio was highly imbalanced at 84.4:15.6. In the Level B college, 248 
questions were raised by the three teachers, among which 177 were displayed questions and 71 were referential questions, and the ratio was 71.4:28.6. While in the Level C college, of the 261 questions posed by the three teachers, 102 were displayed questions and 159 were referential questions, with a ratio of 39.1:60.9. This shows that the higher level the college is, the more desirable the questioning style is. It also shows that only in the Level $\mathrm{C}$ college, the teachers asked more referential questions than display questions, while in both the Level A and Level B colleges, the teachers tended to focus more on display questions.

Then we divided the questions into two levels - high cognitive level and low cognitive level and studied their percentage and ratio. Table 2 presents the relevant data:

Table 2. The frequency of high and low cognitive level questions

\begin{tabular}{c|ccccc}
\hline Teacher & $\begin{array}{c}\text { Total amount } \\
\text { of teachers' } \\
\text { questions }\end{array}$ & $\begin{array}{c}\text { Low coginitive } \\
\text { level questions }\end{array}$ & Percent & $\begin{array}{c}\text { High coginitive } \\
\text { level questions }\end{array}$ & Percent \\
\hline T1 & 62 & 61 & $98.4 \%$ & 1 & $1.6 \%$ \\
T2 & 111 & 108 & $97.3 \%$ & 3 & $2.7 \%$ \\
Level A & $\mathbf{1 7 3}$ & $\mathbf{1 6 9}$ & $\mathbf{9 7 . 7 \%}$ & $\mathbf{4}$ & $\mathbf{2 . 3 \%}$ \\
T3 & 76 & 71 & $94.3 \%$ & 5 & $5.7 \%$ \\
T4 & 80 & 76 & $95.0 \%$ & 4 & $5.0 \%$ \\
T5 & 92 & 87 & $94.6 \%$ & 5 & $5.4 \%$ \\
Level B & $\mathbf{2 4 8}$ & $\mathbf{2 3 4}$ & $\mathbf{9 4 . 4 \%}$ & $\mathbf{1 4}$ & $\mathbf{5 . 6 \%}$ \\
T6 & 83 & 72 & $86.7 \%$ & 11 & $13.3 \%$ \\
T7 & 100 & 69 & $69.0 \%$ & 31 & $31.0 \%$ \\
T8 & 78 & 65 & $83.3 \%$ & 13 & $16.7 \%$ \\
Level C & $\mathbf{2 6 1}$ & $\mathbf{2 0 6}$ & $\mathbf{7 8 . 9 \%}$ & $\mathbf{5 5}$ & $\mathbf{2 1 . 1 \%}$ \\
Total & $\mathbf{6 8 2}$ & $\mathbf{6 0 9}$ & $\mathbf{8 9 . 3 \%}$ & $\mathbf{7 3}$ & $\mathbf{1 0 . 7 \%}$ \\
\hline
\end{tabular}

Note. Level $\mathrm{A}=$ common level; Level $\mathrm{B}=$ provincial level; Level $\mathrm{C}=$ national level.

From the table we can see that the predominant amount of the questions raised in the 8 classes were low cognitive level questions, accounting for $89.3 \%$ of the total amount, while high cognitive level questions only accounted for $10.7 \%$, much lower than the percentage of $20 \%$ we set for a TBLT classroom.

A detailed analysis again shows the striking difference among the teachers in different colleges. Of the 173 questions raised by the two teachers at Level A college, 169 were low cognitive level questions and only 4 were high cognitive questions, with a highly imbalanced ratio of 97.7:2.3. The situation at the Level B college is quite similar: of the 248 questions raised in the classroom, 234 were low cognitive level questions, accounting for $94.4 \%$, while only 14 were high cognitive level questions, sharing only $5.6 \%$. However, the situation in the Level C college is entirely different. Of the 261 questions raised in the class, there were altogether 55 high cognitive level questions, accounting for $21.1 \%$ of the total and exceeding the requirement of $20 \%$ we set for a TBLT classroom.

To study the questioning behavior of the teachers, we first checked how they addressed the questions to the students. The table below shows the distribution of their questions: 
Table 3. The distribution of the teachers' questions

\begin{tabular}{c|cccccc}
\hline Teacher & $\begin{array}{c}\text { Questions } \\
\text { posed by } \\
\text { teacher }\end{array}$ & $\begin{array}{c}\text { Questions } \\
\text { answered by } \\
\text { individual students }\end{array}$ & Percent & $\begin{array}{c}\text { Number of } \\
\text { students in } \\
\text { each class }\end{array}$ & $\begin{array}{c}\text { Number of } \\
\text { individual students } \\
\text { answering questions }\end{array}$ & Percent \\
\hline T1 & 62 & 6 & $9.7 \%$ & 81 & 10 & $12.3 \%$ \\
T2 & 111 & 24 & $21.6 \%$ & 79 & 36 & $45.6 \%$ \\
Level A & $\mathbf{1 7 3}$ & $\mathbf{3 0}$ & $\mathbf{1 7 . 3} \%$ & $\mathbf{1 6 0}$ & $\mathbf{4 6}$ & $\mathbf{2 8 . 8 \%}$ \\
T3 & 76 & 28 & $36.8 \%$ & 74 & 38 & $51.4 \%$ \\
T4 & 80 & 25 & $31.3 \%$ & 73 & 36 & $49.3 \%$ \\
T5 & 92 & 18 & $19.6 \%$ & 72 & 27 & $37.5 \%$ \\
Level B & $\mathbf{2 4 8}$ & $\mathbf{7 1}$ & $\mathbf{2 8 . 6} \%$ & $\mathbf{2 1 9}$ & $\mathbf{1 0 1}$ & $\mathbf{4 6 . 1} \%$ \\
T6 & 83 & 58 & $69.9 \%$ & 54 & 49 & $90.7 \%$ \\
T7 & 100 & 18 & $18.0 \%$ & 57 & 21 & $36.8 \%$ \\
T8 & $\mathbf{7 8}$ & 44 & $56.4 \%$ & 55 & 44 & $80.0 \%$ \\
Level C & $\mathbf{2 6 1}$ & $\mathbf{1 2 0}$ & $\mathbf{4 6 . 0} \%$ & $\mathbf{1 6 6}$ & $\mathbf{1 1 4}$ & $\mathbf{6 8 . 7} \%$ \\
Total & $\mathbf{6 8 2}$ & $\mathbf{2 2 1}$ & $\mathbf{3 2 . 4} \%$ & $\mathbf{5 4 5}$ & $\mathbf{2 6 1}$ & $\mathbf{4 7 . 9} \%$ \\
\hline
\end{tabular}

Note. Level A=common level; Level B=provincial level; Level C=national level.

Table 3 shows that of the total amount of questions, only 221 were personal solicit, accounting for $32.4 \%$, and of the 545 students, only 261 or $47.9 \%$ got the opportunities to answer. This shows that in general, the students did not have equal and sufficient opportunities to communicate with the teacher.

A further analysis again reveals the differences among the 8 teachers. The two teachers in the Level A college only asked 30 questions for personal solicit, and of the 160students, less than $1 / 3$ of the students had the opportunity to answer. The situation in the Level B college is better: 71 questions were addressed to the individual students, and 101 students out of 219 got the chance to answer. The most desirable situation occurred in the Level C college: 120 questions were for personal solicit, and 114 students, about $68.7 \%$ of the 166 students, got the opportunity to answer. This data shows that the questioning behavior in the Level $\mathrm{C}$ college meets the requirement of a TBLT classroom, is acceptable in the Level B college, but not desirable in the Level A college.

Finally, we checked the amount of questions initiated by the students in the 8 English classes and got the data below:

Table 4. Questions initiated by the students

\begin{tabular}{c|cc}
\hline Teacher & Student- initiated questions & Questions/per class \\
\hline T1 & 2 & 2 \\
T2 & 3 & 3 \\
Level A & $\mathbf{5}$ & $\mathbf{2 . 5}$ \\
T3 & 3 & 3 \\
T4 & 4 & 4 \\
T5 & 2 & 2 \\
Level B & $\mathbf{9}$ & $\mathbf{3}$ \\
T6 & 7 & 7 \\
T7 & 4 & 4 \\
T8 & 6 & 6 \\
Level C & $\mathbf{1 7}$ & $\mathbf{5 . 7}$ \\
Total & $\mathbf{3 1}$ & $\mathbf{3 . 9}$ \\
\hline
\end{tabular}

Note. Level A=common level; Level $\mathrm{B}=$ provincial level; Level $\mathrm{C}=$ national level. 
From the table above, we can see that only 31 questions were initiated by the students, accounting for only $4.3 \%$ of the total amount of questions raised in class $(682+31=713)$. Although there are some differences amount the eight classes in colleges at different levels, the differences were insignificant in general.

To find out the reasons behind the differences of questioning style in the English classroom of the three colleges at different levels, we studied the responses of the teachers in the semi-structured interview and those of the students in the focus group discussion.

In the interview with the teachers, the teachers in both Level A and Level B colleges admitted that they knew very little about the question types and their functions in TBLT classes, that they posed questions mainly by intuition or based on their previous teaching and learning experience, and that their purpose of questioning was mostly to check text comprehension, grammar and vocabulary mastery. On the contrary, the three teachers in the Level C college not only knew clearly the four different types of questions, they were also quite clear about their different functions. They said that they were required to ask more referential questions in class to stimulate the students to use foreign language to express themselves and they purposefully tried to use more high cognitive level questions to encourage the students to think critically.

When talking about the questioning behavior, the teachers in both the Level A and Level B colleges said that they asked fewer questions for personal solicit because the students were reluctant to answer questions in class due to their poor language proficiency. In additition, they have so many students in their classroom that they can't give every student a chance to answer the question. What's more, the time was so limited that they could not spend too much time waiting for the students to answer. They also admitted that the focus of their teaching was on grammar and vocabulary, which were essential to help the students pass the CET4 and CET6. In contrast, the teachers in the Level C college said that they have comparatively fewer students in their class. Besides, they tried their best to give every student equal opportunity to answer questions, and that the students were eager to answer questions and communicate with them.

The teachers' opinions were confirmed by the responses of the students in the focus group discussion. The students in both the Level A and Level B colleges said that their teachers mostly asked them questions to which there were ready answers, that most of the questions were simple, and most of them focused on text comprehension, grammar and vocabulary. Besides, they also admitted that they were reluctant to answer questions in class for lack of confidence. While the students in the Level C college said that their teacher's questions were quite challenging, that they were often required to provide personal experience and opinions in answering the questions. What is more, they were quite active and highly participative in answering questions because they found the questions were quite interesting.

When it comes to the issue of student initiating questions in class, both the teachers and students admitted that it was quite unusual for the students to ask the teacher questions in class. Although the teachers in Level C college said that they did encourage the students to ask questions in class, the result was still not quite desirable. We believe that three reasons account for this phenomenon. First of all, it is considered inappropriate for students to ask teachers questions in class in the traditional Chinese classroom. This was confirmed by the response of a student who said that if she asked questions, it would disrupt the teacher's teaching. This also echoed the findings in Tan's (2007) research: "Chinese students have been trained to respect and obey the teacher, conform to the collective benefits at the cost of individual interest."

Secondly, many students preferred to ask their peers instead of their teacher during group work or find the answers on their own after class when they had a question. This was also confirmed by the responses of the students.

Finally, students' low language proficiency and low motivation in learning also prevented them from asking questions, especially in Level A and Level B colleges. Just as a teacher from the Level A college said, "One of the main reasons for the students not willing to ask questions is their low English proficiency level and low motivation in learning English."

To summarize, we can say that in general, the English classroom in China did not change much after all these years of reform from the perspective of questioning style. However, in the national model colleges where the students' English proficiency was much higher and where the teachers were better trained, the English classroom really displayed the characteristics of a TBLT classroom. Therefore, the students' English proficiency and the teachers' in-service training seem to be two decisive factors that determine the questioning style in class as well as the nature of the English classroom. Besides, the pressure of College English Test (B and 4 and 6) may also be a factor that affects the questioning style in class, although such effect was much weaker in the national model college. Last but not least, the class size also plays an important role in affecting the questioning style in class. 
The more students one class has, the less chances the students will have to answer teacher's questions.

\section{Conclusion and Implications}

From this study, we can have a general understanding of the English classroom in China from the perspective of questioning style. Guangdong has been considered one of the most advanced places in English education, and the Guangdong Provincial Education Department has been taking an active part in promoting TBLT approach in college English education. Although in all the three colleges, the teachers did assign students different tasks to perform in class and seemed to be adopting the TBLT approach, their questioning style has revealed that they have not totally changed their education concept or their teaching behavior in class. The same can be said about students in the colleges. Their major concern in English learning is not for communication, but for mastering grammars and new words and finally for passing examinations. As a result, for those students who have English learning problems, they are usually less motivated in English learning and are quite passive in class.

In order to develop higher vocational college students' communicative competence in English and their overall proficiency, first of all, all teachers should be given equal and sufficient training opportunities to develop a solid understanding of TBLT. Secondly, we should reform College English Test further and focus more on the students' communicative competence rather than their linguistic knowledge so as to generate favorable washback on teaching and learning. In addition, we should reduce the class size so that everybody in the class can get more chances to answer questions and communicate in English. Last but not least teachers will need to adopt more student-centered and communicative ways of teaching and use more referential and high cognitive level questions, encourage students to initiate questions and distribute questions evenly and widely so as to create opportunities for every student to use the target language to express themselves as well as to enhance their interests in language learning.

\section{Acknowledgements}

This study is sponsored by the English Teaching Research Centre of Guangdong University of Foreign Studies.

\section{References}

Allwright, D., \& Bailey, K. (1991). Focus on the Language Classroom: An Introduction to Classroom Research for Language Teachers. Cambridge: Cambridge University Press.

Bloom, B. S. (1956). Taxonomy of Educational Objectives: The Classification of Educational Goals. Handbook I: Cognitive Domain. New York: David McKay.

Han, X. (2007). A Study on Teacher's Questions in Classroom Interaction (Master's thesis, Northeast Normal University, Changchun).

Krashan, S. (1994). The input hypothesis and its rivals. In N. Ellis (Ed.), Implicit and explicit learning of languages. London: Academic Press.

Long, M. H., \& Sato, C. J. (1983). Classroom Foreigner Talks Discourse: Forms and Functions of Teachers' Questions. In H. Selinger, \& M. Long (Eds.), Classroom Oriented Research in Second Language Acquisition. Rowley, Mass.: Newbury House.

Long, M. H. (1996). The Role of Linguistic Environment in Second Language Acquisition. In W. C. Ritchie, \& T. K. Bhatia (Eds.), Handbook of Second Language Acquisition. Sand Diego, CA: Academic Press.

Sari, L. (1998). Effective Questioning Techniques: In Theory and Practice. In P. M. Leah (Ed.), Studies in Teaching. Winston Salem, NC: Wake Forest University.

Shen, P. (2012). A Case Study of Teacher's Questioning and Students' Critical Thinking in College EFL Reading

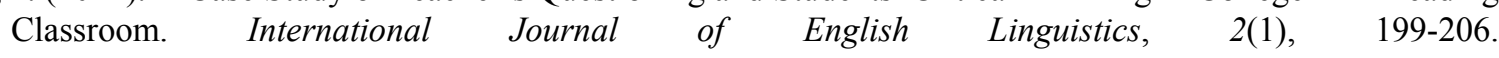
http://dx.doi.org/10.5539/ijel.v2n1p199

Swain, M. (1995). Three Functions of Output in Second Language Learning. In G. Cook, \& B. Seidlhofer (Eds.), Principles \& Practice in Applied Linguistics. Oxford: Oxford University Press.

Tan, Z. (2007). Questioning in Chinese University EL Classrooms: what lies beyond it? RELC Journal, 38, 87-103. http://dx.doi.org/10.1177/0033688206076161

Wang, X. (2003). Study on Teacher Questioning at EFL Classes (Master's thesis, Jilin University, Changchun). 


\section{Appendix}

The classroom observation checklist

\begin{tabular}{|c|c|c|c|}
\hline & Description & Examples & Quantity \\
\hline $\begin{array}{l}\text { T-initiated } \\
\text { questions }\end{array}$ & $\begin{array}{l}\text { The question initiated by the } \\
\text { teacher }\end{array}$ & ----------------------------- & \\
\hline $\begin{array}{l}\text { S-initiated } \\
\text { questions }\end{array}$ & $\begin{array}{l}\text { The question initiated by the } \\
\text { students }\end{array}$ & ----------------------------- & \\
\hline $\begin{array}{l}\text { Display } \\
\text { questions }\end{array}$ & $\begin{array}{l}\text { 1. answer already known by the } \\
\text { teacher } \\
\text { 2. often require limited, } \\
\text { sometimes one word answers } \\
\text { 3. display knowledge acquired }\end{array}$ & $\begin{array}{l}\text { 1. When and where was the first cell phone } \\
\text { produced? } \\
\text { 2. Shall we talk loudly in public? }\end{array}$ & \\
\hline $\begin{array}{l}\text { Referential } \\
\text { questions }\end{array}$ & $\begin{array}{l}\text { 1. answer unknown by the teacher } \\
\text { 2. promote interaction resembling } \\
\text { a non-classroom setting } \\
\text { 3. stimulate complex and lengthy } \\
\text { language output } \\
\text { 4. are exploratory }\end{array}$ & $\begin{array}{l}\text { 1. If you were the manager, would you do the } \\
\text { same thing and why? } \\
2 \text {. What bad manners should we avoid when we } \\
\text { travel around the world? }\end{array}$ & \\
\hline $\begin{array}{l}\text { Low } \\
\text { cognitive } \\
\text { level } \\
\text { questions }\end{array}$ & $\begin{array}{l}\text { 1. concerning "what" "when"and } \\
\text { "where" } \\
\text { 2. asking for a discrete piece of } \\
\text { information that can be recalled }\end{array}$ & $\begin{array}{l}\text { 1. What is the appropriate way to use the knife } \\
\text { and fork? } \\
\text { 2. What word does an adjective modify? } \\
\text { 3. According to the rules of subject and verb } \\
\text { agreement, which sentence is right? }\end{array}$ & \\
\hline $\begin{array}{l}\text { High } \\
\text { cognitive } \\
\text { level } \\
\text { questions }\end{array}$ & $\begin{array}{l}\text { 1. concerning "why" and "how", } \\
\text { 2. requiring the respondent to } \\
\text { analyze, synthesize or evaluate } \\
\text { pieces of information to form a } \\
\text { new conclusion }\end{array}$ & $\begin{array}{l}\text { 1. What do you think was the writer's reason for } \\
\text { writing this article? } \\
\text { 2. Write a plan by which you can make the } \\
\text { community environment conscious. } \\
\text { 3. What's your opinion of mass production? }\end{array}$ & \\
\hline Whole & Questions answered in chorus & ----------------------------- & \\
\hline Individual & $\begin{array}{l}\text { Questions answered by individual } \\
\text { either voluntarily or by } \\
\text { nomination }\end{array}$ & ---------------------------- & \\
\hline
\end{tabular}

\section{Copyrights}

Copyright for this article is retained by the author(s), with first publication rights granted to the journal.

This is an open-access article distributed under the terms and conditions of the Creative Commons Attribution license (http://creativecommons.org/licenses/by/3.0/). 